\title{
Part One, Book One: God and his Being, or Metaphysics
}

\author{
Francesco Paolo Ciglia
}

The present contribution sets out to critically explore some very specific, yet notably relevant aspects of Rosenzweig's reflection about the theological question. To reach this end, this same contribution will provide a first and elementary introduction to the reading of a particular section of the thinker's philosophical masterpiece, The Star of Redemption ${ }^{19}$, in which are cast the basic foundations of the complex, and much more ample reflection on the subject, which will be later articulated throughout the entire course of the work. The section in question is represented by Book One of Part One of Star (henceforth, Star I.1) ${ }^{20}$.

Before beginning our exploration, it seems important to underline the absolutely undeniable fact that the thinker's philosophical masterpiece presents

${ }^{19}$ F. Rosenzweig, Der Stern der Erlösung, Frankfurt a.M. 1921; $2^{\text {nd }}$ ed., ibid., $1930 ; 3^{\text {rd }}$ ed., Heidelberg 1954; $4^{\text {th }}$ ed. in: F. Rosenzweig, Der Mensch und sein Werk. Gesammelte Schriften, 2. Abteilung: Der Stern der Erlösung, Haag 1976; $5^{\text {th }}$ ed., Frankfurt a.M. 1988. Our citations of the work, mentioned hereafter as: GS II, followed by the page number, will be taken from the $4^{\text {th }}$ ed., just cited.

${ }^{20}$ GS II, 25-43.

How to cite this book chapter:

Ciglia, F. P. 2021. Part One, Book One: God and his Being, or Metaphysics. In: Brasser, M., Bojanić, P. and Ciglia, F. P. (eds.) The Star for Beginners: Introductions to the Magnum Opus of Franz Rosenzweig. Pp. 23-40. London: Ubiquity Press. DOI: https://doi.org/10.5334/bco.d. License: CC-BY 
itself to an interpretative approach as a philosophical work of extreme difficulty. It, at times, appears even obscure and enigmatic, and certainly not only to those who approach it for the first time! The difficulty that marks the entire work appears to grow, if that is possible, in a particular way, one would say to its highest degree, through the course of Part One. This notice does not in any way aim to discourage the reader who intends to face the work as a beginner; on the contrary it is an encouragement to bravely face a true interpretative challenge, the undertaking of which will not fail to amply repay the profuse efforts it requires.

\section{The context}

Our analysis begins with a very rapid contextualization of Star I.1, within the work's overall economy.

The Star is subdivided in three basic Parts, each of which contains three large sections of text, which the thinker denominates Books. Each Part of the Star is accompanied by an introductory text and a conclusive text, the latter, for the first two Books, has the function of mediating the transition to the following Part; while for Book Three, it serves as the closure of the entire speculative itinerary traveled throughout the course of the work.

The work's three main parts seek to peruse the three fundamental dimensions which, according to the thinker, constitute the plot of all reality. The dimensions in question, which are based, in some way in succession, each on the preceding one, are called by the thinker respectively: "everlasting primordial world" 21 , "ever renewed world"22, and "eternal over-world"23 [immerwährende Vorwelt, allzeiterneurte Welt, ewige Überwelt].

The work's central part - the Second Part, which deals with the "ever renewed world"- enjoys a marked preeminence with respect to the other two parts. It searches the horizon within which our common daily human existence takes place inside the world. This preeminence cannot astound, if one considers the fact that Rosenzweig's meditation understands itself in terms of erfahrende Philosophie - literally, "experiential philosophy" - that is, in terms of a "militant" philosophy working at the front lines in the elaboration of a critical reflection of the concrete existence of man within the world ${ }^{24}$.

\footnotetext{
21 Ibid., 1-100.

${ }^{22}$ Ibid., 101-292.

${ }^{23}$ Ibid., 293-472.
}

${ }^{24}$ Franz Rosenzweig, Das neue Denken. Einige nachträgliche Bemerkungen zum Stern der Erlösung, initially published in “Der Morgen”, October 1925, it appeared in various collections, before coming together in: F. Rosenzweig, Der Mensch und sein Werk. Gesammelte Schriften, 3. Abteilung: Zweistromland. Kleinere Schriften zu Glauben und Denken, Dordrecht/ 
The Third Part of the work - which is "about the eternal over-world" thematizes that particular ontological dimension toward which a complex framework of relational dynamisms, which fully permeate and deeply penetrate the actual makeup of the world we daily experience, appears to be intentionally and spasmodically projected. These dynamisms prefigure, and in a certain sense also prophesy in an allusive manner, and in the form of "already" but "not yet", a complete and total fulfillment of the world of our daily experience - an eschatological fulfillment. Employing a term which comes from the biblical tradition, the thinker names this fulfillment "redemption". It represents the primary object of teleological dynamism - or of the speculative hope - which takes flesh in the entire work, and is significantly reflected even in its very title.

Part One of the Star - the part containing the Book which is of interest to us in this essay - attempts to bring to the light a dimension of reality that is normally invisible and therefore not accessible from the perspective of our most common and daily existence within the world. In this dimension, which can only be reconstructed in an indirect way through - so to speak - circumstantial procedures, lie the primordial or elementary foundations upon which our existence within the world rests. This "primordial-worldly" dimension is much poorer, far rougher, and more abstract than the worldly sphere within which we normally live, yet it constitutes the necessary condition - the condition of possibility or conditio sine qua non - of the worldly sphere in question. However, it cannot represent the worldly sphere's sufficient condition. There subsists, between "primordial-world" and "world", an ontological gap that is unfillable, and therefore absolutely inexplicable at the level of pure thought.

The primordial or elementary foundations - the "primordial-worldly" foundations - of the world dimension within which we normally live are represented, according to Rosenzweig, by the three classical figures of the mythical God, the plastic world ${ }^{25}$ and the tragic man, which were brought to light with an exceptional clarity in the literary and religious culture of Ancient Greece. These same figures, after having undergone complex reworking in a speculative key, will constitute the privileged objects of the three fundamental metaphysical sciences, which are: rational theology, rational cosmology and

Boston/Lancaster 1984, 139-161. The essay, hereafter mentioned as GS III, followed by the page number, will be be cited according to the 1984 edition. The self-understanding of Rosenzweig's thought in terms of "erfahrende Philosophie" recurs in GS III, 144.

25 The "plastic world", evoked here, is explored in the First Part of the Star, and must not be mistaken for the "ever renewed world" which constitutes the object of the work's Second Part. In the first case, it is one of the three constitutive elements of the "primordial-world" - elements which are specific and well circumscribed. In the second case, it is much broader dimension of reality, that in which (as we have said) our daily life is immersed in the world. 
rational psychology. The sciences in question will represent, in the end, the load-bearing structure of the entire Western onto-theological tradition.

\section{The theme}

The three Books which compose Part One of the Star are dedicated to the three fundamental speculative figures that constitute the "primordial-world", that is to say, in order: to $\operatorname{God}^{26}$, to the world ${ }^{27}$ and to $\mathrm{man}^{28}$. The three figures in question, in their peculiar primordial-worldly conformation, are understood by the thinker as "elements" [Elemente ${ }^{29}$. It is important to underline the fact that this definition does not exhaust the peculiar richness and the overall and ultimate meaning of the figures just evoked.

Even if their pre-worldly conformation is undoubtedly and indispensably presumed, the divine, worldly, and human horizons as they appear and are experienced within what the thinker names "ever renewed world" - that is, as we know, within the most common daily experience of man within the world transcend it, and radically transfigure it.

The Book of Rosenzweig's masterpiece which we are to examine - that is Star I. 1 - bears an extremely meaningful title which immediately unveils the object it seeks to portray and the modalities, strongly ambiguous or even misleading as they may be, which it proposes to adopt from the beginning. The title sounds much like this: God and his Being or metaphysics [Gott und sein Sein oder Metaphysik] $]^{30}$.

In order to begin treating the Book in question, I would like to preliminarily propose some brief reflections, first of all, about its strategic placement within, not only Part One of the Star, but also of the entire work; secondly I'd like to reflect on the overall speculative layout of the subject, as it seems to transpire from the title.

\subsection{Strategic placement}

Rosenzweig's choice of placing the philosophical question about the "elemental God" in Star I.1, and consequently at the very opening - at the incipit - of the entire work cannot be the product of chance. This same choice could not but produce, in fact - and thus, even beyond the thinker's explicit intentions - general speculative effects of enormous bearing for the entire work. One

\footnotetext{
${ }^{26}$ See GS II, 25-43.

27 Ibid., 44-66.

${ }^{28}$ Ibid., 67-90.

${ }^{29}$ Ibid., 1.

30 Ibid., 25.
} 
could sustain instead that the thinker's explicit intentions, with reference to this choice, and the speculative effects which it in fact produces on the entire work, intertwine in a truly singular dialectic. In an important programmatic text from $1925^{31}$, the thinker in fact peremptorily denies that the placement of the philosophical question about the "elemental" God in Star I.1 expresses the intention of clearly favoring that question over the meditations on other issues, which are respectively, cosmological and anthropological, and which will be treated in Star I.2 and Star I.3. The thinker declares, in the same sense, that Star I could just as well have begun, with the cosmological question as with the anthropological question ${ }^{32}$. In fact, at least in Star I, the thinker intends to pursue a very particular speculative strategy, which tends to value and exalt to the highest degree the absolutely equal worth of the three "elements", together with their irreducible difference, and their absolute reciprocal independence.

However, the subsequent developments of the theological question throughout the work in fact create radically different speculative dynamics. In Star II, for example, out of the three relational events that constitute the object of its three Books - that is to say, creation $^{33}$, revelation ${ }^{34}$ and redemption ${ }^{35}$-, two creation and revelation - find their primordial motivation and their absolute point of origin precisely in God. Star III.3, which is the last Book of the entire work ${ }^{36}$, culminates in a passionate meditation on God, intended as conclusive and definitive "eternal truth". The brief text entitled Door or Gate [Tor ${ }^{37}$, which concludes the work after Star III.3, finally stops with a sort of muted contemplation of God's very face.

Therefore the theological question, even if presented through radically different modalities, opens and closes the entire Rosenzweigian work. Thus it seems to delineate a sort of powerful speculative inclusion - a genuinely theological inclusion - which, in embracing the entire philosophical itinerary covered by the Star, cannot but shed a singular light on it, a light of absolutely unequivocal meaning.

\subsection{Speculative setup}

The title given to Star I.1 by the author, generates absolutely misleading impressions, even in the most common of readers endowed with a discreet philosophical background. The short circuit which the title in question establishes

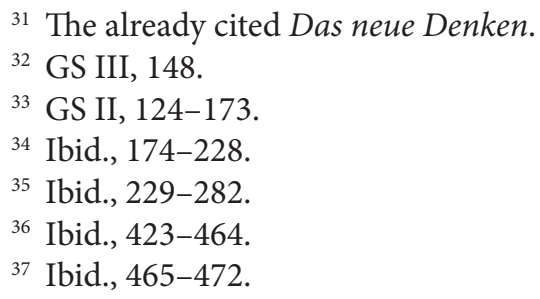


between the question of God, the question of being - or ontology - and metaphysics, seems to refer to the well-known - and classical - Aristotelian theorization. Aristotle's first philosophy, later named "metaphysics", is centered, as is well known, in a privileged way on the question of being and the founding structures of the latter, amongst which the substance or ousia stands out because of its importance. Among the innumerable substances that populate the physical and metaphysical universe explored by Aristotle, the divine substance stands out because of its absolute excellence. Aristotelian metaphysics as a whole appears to find its arrival point and highest apex in theology ${ }^{38}$.

In its reuse of terminology consecrated by the classical tradition, Rosenzweig's treatment of the "elemental" God appears to violently introduce - to utilize a well-known New Testament metaphor - some "absolutely new wine" in "old wineskins". These last ones, as we shall see together, will explode under the bursting action of the Rosenzweigian theological reflection's new wine, yielding results of rare and extreme originality.

\section{One God, two faces}

The meditation on God, grasped as "element" of the "primordial world" described by Rosenzweig in Star I.1, unfolds along the tracks of a very precise methodological itinerary. The starting point of such an itinerary is represented by a very special, and somewhat paradoxical, understanding of the "element" God. The "element" in question is assigned two configurations which seem contradictory but are in reality very closely connected by the underground logic of deep solidarity. In fact they are two different, yet complementary, faces of the same medal. Let us begin to examine them right away.

\subsection{God as "nothing [Nichts]"}

At first sight the beginning of Rosenzweig's meditation on the "elemental" God seems inspired by the classical tradition of "negative theology"- yet here too, it is a only a misleading impression. From the very outset of his theological meditation, the thinker hastens to say: "We know nothing about God"39. In front of the human reason's approach, God presents himself as nothing, at least at first, according to Rosenzweig. Therefore philosophical meditation about God cannot begin if not from a radical non-knowledge about God. In what terms exactly must the nothing of God be understood? Two essential clarifications are to be offered on this matter.

\footnotetext{
${ }^{38}$ Aristotle, Metaphysics, VI (E) 1, 1026 a 15-20, XI (K) 7, 1064 b 3, and XII (L) 7, 1072 a $19-1073$ b 3.

${ }^{39}$ GS II, 25.
} 


\subsubsection{The divine nothing as a problem}

The nothing found by human reason in the moment in which it questions itself about God is not banally a nothingness, but rather it is something; it could well be said, it is something which makes one think. It is not an absolute void, the void of pure and simple absence or non-existence. One could perhaps say, metaphorically speaking, that the divine nothing is akin to a sort of extremely dense and compact, obscure cloud, which hides in its depths something that is inaccessible, at least initially. The divine nothing is therefore a nothing that is full, loaded, or rather, overloaded, with content. It is the nothing of God's hiddenness or veiledness in the eyes of human reason. On the other hand, the same thinker explicitly points out that to begin the meditation about God considering his nothing is no different than saying that for us - at least initially -, God cannot be other than a problem ${ }^{40}$. The nothing which reason stumbles upon in its search for God would then coincide with the extreme, absolute, problematicity of his intentional objective.

\subsubsection{Determinate nothing}

Not-knowing about God, the nothing which human reason stumbles upon in its approach to the theological question, must not be understood to be, in Rosenzweig' s perspective, a -general or generic - universal nothing; that is to say an all-embracing or total nothing. The nothing of the knowledge about God is not the full-court nothing or überhaupt, but, on the contrary, it is a nothing, that is, an absolutely determined and circumscribed nothing. It is precisely the type of nothing which the human reason faces when it walks down a specific research path, that is to say a path that should lead to God. It is the nothing of God or of human knowledge about God. Here the objective genitive of the nothing of God appears marked and enlivened by an intentional dynamism and by a global orientation that are absolutely unequivocable. The nothing of God indicates a very precise direction of movement that points towards the obscure cloud of the knowledge about God.

\subsection{God as factuality [Tatsächlichkeit]}

Let us now pass to the second configuration; it is different, yet complementary to the first Rosenzweigian understanding of the "elemental" God. Comparing both faces of the same medal, of which we spoke earlier, cannot avoid producing surprise and disconcert; it cannot but generate an authentic paradox. Besides the understanding of God in terms of problematicity, in terms of a "nothing" which human rationality seeks to grasp, the thinker is not afraid to - quite

40 Ibid., 27. 
brusquely - present an understanding of God in terms of an absolutely obvious and immediate fact. The same God who, in the eyes of human reason, is enveloped by an obscure and impenetrable cloud represents, contemporaneously, for reason itself, a sort of irreducible positum, that is to say: an imprescindable and undeniable factuality. Human reason is neither capable of producing nor building this positum by itself and with its own formidable resources; nor, one could well say eyeing the latest developments of post-modern debate, is reason capable to deconstruct the positum through speculative procedures, be they more or less sophisticated. In the previously cited text from 1925, the thinker affirms that we know equally little and much, nothing and everything about God - and about the two other "elements", which are the world and man. This "knowing much" or "knowing everything" about God and about the other elements reaches man, according to the thinker, through a source radically different from pure philosophical thought. He intends to refer to "anschauliches Wissen der Erfahrung", or intuitive knowledge - which is absolutely clear, absolutely evident - from experience, from which philosophical thought cannot and absolutely must not prescind, but with which a deep, or better yet constitutive, interrelation, must be constantly maintained - even when there are contrasts and conflict. In the end, the contrast and conflict will reveal themselves to be particularly fecund.

In an important part of the Star, which is outside the Book we are now analyzing, Rosenzweig designates the "elemental" God - but also equally, the other two "elements" - with the high-risk - yet nonetheless highly significative - expression of "irrational object". The thinker prudently placed the adjective "irrational" between quotation marks. The expression's context makes clear, beyond any shadow of doubt, that the term "irrational" must not be interpreted literally here, as if it meant "non-rational", "opposed" or "contrary" to reason. Otherwise the quotation marks would not have been necessary at all. "Irrational" here undoubtedly stands for "meta-rational" or "trans-rational". The "elemental" God is neither a product of reason nor appears to be exhaustively graspable through reason's resources. The "elemental" God, in a certain sense, imposes or proposes himself to reason, which has the task of grasping him, focusing on him, critically problematizing him and exploring him up to the point allowed by reason's constitutive limits.

The ambiguity of an "elemental" God, who constitutively oscillates between problematicity and obviousness, between nullity and immediate factuality, represents a real provocation which human reason cannot escape. The provocation shows itself to be a real challenge as it is contextualized within the same historical and problematic horizon in which the dark, grave and terrible Nietzschean announcement -"God is dead" - resounded with strength. It was an announcement which Rosenzweig knew very well and one he demonstrably considered with extreme seriousness within his philosophical masterpiece. It could be said, not without a bit of irony, that God, even when dead, continues to make 
problems for human reason - or to be a problem for it. Perhaps this same God gives us problems and constitutes a problem more if dead than alive.

\subsection{Deus absconditus sed tamen non ignotus}

The profound ambiguity of the Rosenzweigian "elemental" God could be enlightened, in an extremely synthesized manner, by two historical examples, which I analyze here with the greatest freedom, and therefore without any philological preoccupation.

The first example could be given by the docta ignorantia, a concept known to have been developed by Nicholas of $\mathrm{Cusa}^{41}$. This reference must necessarily be accompanied by an essential clarification. The docta ignorantia of which we speak, in contrast to the Cusanian understanding, which Rosenzweig polemically evoked in Star I. $1^{42}$, only constitutes a starting point for our thinker - and not an endpoint- in a discourse about God that intends to go much further. In the Rosenzweigian perspective, the docta ignorantia wishes to become, ever wiser, and ever less ignorant.

The second example could be represented by the well known Augustinian expression that expresses the complexity of the human being's relationship with the difficult question of time. Augustine poses the question: "quid enim est tempus?", that is: "what in fact is time?" He answers: "Si nemo ex me quaerat, scio; si quaerenti explicare velim, nescio", that is: "If no-one ask me, I know; if I wish to explain it to him who asks, I know not" ${ }^{33}$. The first part of the Augustinian statement lends itself as a good example of the second face of the medal of the Rosenzweigian understanding of the "elemental" God. God, as philosophically problematic and inexplicable as he may be, presents himself as absolute factuality, as positive givenness, which is always newly offered to us by the intuitive knowledge of concrete experience. This God is present, in some way, immediately and unreflectively, within or before human reason. The God who springs forth from Rosenzweig's considerations presents himself then as a hidden, but not completely unknown, God: Deus absconditus sed tamen non ignotus.

\section{Toward positive theology}

In Rosenzweig's view nonetheless, the configuration of the "elemental" God in the modalities we have just examined, does not represent the arrival point of

${ }^{41}$ Nicholas of Cusa, De docta ignorantia [1440]. The expression that is of interest to us is already found in the work's Capitulum I, Liber Primus, in addition to the title and throughout the course of the work.

${ }^{42}$ GS II, 25.

43 Augustine of Hippo, Confessiones, XI, XIV, 17. 
his meditation on this theme. On the contrary, negative - and factual - theology together represent the starting point of a much more ambitious research itinerary that wishes to go much further. In the end, the thinker in fact aims to achieve some form of positive knowledge about God; this knowledge is, at least initially, only "elemental". How then can one exit from the nothing of knowledge or from non-knowledge about God, how can it be left behind?

\subsection{Two paths of research}

Exiting, and therefore, even if at the embryonic or "elemental" stage, acquiring some form of positive knowledge about God, can happen according to Rosenzweig, along the road of two well defined paths of research. They present themselves as, and in fact are, profoundly different one from the other - frankly they are opposites. The figure of the divine which the thinker wants to delineate in Star I.1 gushes forth from their combined and synergetic action.

The first of these two paths follows the sign marked yes, affirmation, position or positivity. The second path, in an opposite manner, develops along the way of no, of negation or negativity. For the thinker however, within this specific theorization, positivity and negativity do not acquire, in any way, evaluative meaning, but rather are intended in a strictly descriptive sense. Both research paths start out from the originary and initial non-knowledge or nothing of God. Precisely for this reason, they present and continue to maintain a very close relationship - more properly said a constitutive relationship - with this same nothing or non-knowledge. In the thinker's characteristic philosophical terminology, the first path presents itself - and is designated as - that of "the affirmation of the not nothing [Bejahung des Nichtnichts]", the second path instead is "negation of the nothing [Verneinung des Nichts]"44.

\subsection{A polar theology}

The terminology used by Rosenzweig at this point, and above all the philosophical conceptuality that appears to be underpinning this same terminology, doubtlessly present themselves as being particularly difficult to comprehend; let us say that they are frankly abstruse. They come from a plot of very precise historic-speculative referents, which it is clearly not possible to suitably examine in depth here. For this reason we would like to suggest an overall interpretive hypothesis, which we are glad to submit to an open critical analysis.

To storm the conceptual fortress erected by the thinker here before the eyes of his unfortunate readers, I would like to formulate two preliminary questions which aim to introduce my interpretive hypothesis and make it understandable.

${ }^{44}$ GS II, 26. 
Let us begin by asking: According to the thinker, why is it necessary to follow two research paths, and not only one, to pass from the obscure horizon of the non-knowledge of God to a form of positive knowledge about him?

Let us immediately add a second question to the first: why are the two paths placed under the signs of two reciprocally opposite polarities?

In order to answer these questions it is necessary to articulate some general considerations from which will emerge the characteristic speculative profile which the thinker intends to attribute to his conception of the "elemental" divine.

With reference to the first question which we have just now stated one must note that the peculiar figure of the "elemental" God, which Rosenzweig wishes to propose, does not take up the physiognomy of a flatly unidimensional, absolutely rigid, compact and homogeneous, monolithic ontological boulder. Quite on the contrary, the thinker has in mind a multidimensional, full-circle and richly articulated vision of the divine. A single way of access to the divine in question would not be capable to adequately grasp its constitutive complexity. Each of the two research paths for a positive knowledge of Rosenzweig's "elemental" God will then have the task of enlightening a different aspect of the God in question.

In reference to the second question it seems important to mention that the very figure of the divine which Rosenzweig wishes to clarify, does not present itself as a fundamentally static reality - one that is, so to speak, perennially coincident with itself. Rosenzweig's "elemental" God will soon reveal himself to be pervaded by an unstoppable disquietude - a vital disquietude. He will present himself as a sort of force field, perennially inhabited and agitated by two opposite and synergetic polarities, which are in acute and irreducible tension. Precisely for this reason the two ways of research that unlock the access to the figure of Rosenzweig's "elemental" God acquire a different polar disposition they are reciprocally opposite. Each one of them will reach one of the two different dynamic poles that constitute the figure of the "elemental" God.

\subsection{Affirmation of the not-nothing}

As we have said earlier, the "affirmation of the not-nothing" represents the first way out of the nothing of God, or the non-knowledge about God. The Rosenzweigian expression appears to be quite contorted and convoluted, and thus precisely undecipherable. What does he wish to indicate? Why the double negative - not-nothing! - if the reciprocal negative elision of its constitutive elements ends up as an affirmation? Isn't the "not-nothing", which establishes itself along the first way out of the divine nothing, "something"?

In fact the thinker uses the expression "something" in his text to explain the meaning of the not-nothing which is affirmed along the first way out of non-knowledge of the "elemental". Nonetheless, he uses the expression very 
cautiously, in our text ${ }^{45}$, it is found in some cases between quotation marks, and is constantly accompanied by the denunciation of its substantial inadequacy to describe exactly what the thinker has in mind.

To explain the deep motivations of the extreme reluctance with which the thinker uses the term "something" to suggest the idea of "not-nothing", one could hypothesize that the same term must have appeared to him as if overburdened by disturbing reverberations, produced, inevitably, by the term's timeless usage in the context of the philosophical tradition. The term "something [Etwas]" cannot avoid evoking, in the mind of the well-educated reader, the idea of the Greek tode ti, or of quid and quidditas, which emerge from the semantic horizon of the Latin language. These terms irresistibly evoke the idea of an absolutely determined and exactly circumscribed essence. This idea appears to be too narrow and much too well defined for what the thinker has in mind. On the other hand, the "not nothing" in its inelegant use of the double negative, holds the advantage of presenting itself as being much broader, much more undefined, undetermined and all-embracing than "something" 46 . Thus, the first way out from the nothing of God, affirms something positive, yet its positivity is absolutely open and boundless. In conclusion this way affirms an essence, yet one that is absolutely not de-fined or de-termined. What this undefined and undetermined essence could mean in reference to God will be examined shortly.

\subsection{Negation of the nothing}

The "negation of nothing" represents the second way out from the nothing of God or from the non-knowledge about him. It is evidently a totally different research itinerary than the first. The path of "no", "negation" or "negativity" immediately presents itself as being much more traumatic than the "yes" path. The "negation of nothing" as such must mark a cut, a break or a violent tear from the nothing which it detaches itself from. Where does such a negation lead to exactly? Calling to mind an age-old principle of the philosophical tradition, according to which "omnis determinatio est negatio", the thinker is able to present negation as de-finition, and thus as the position of a finite being, as in delimitation, and de-termination. However these are unlike the - absolutely static and tranquil - definition, or delimitation or determination, which traditional logic places before our eyes. In fact they are the fruit of a dynamic process of detachment from the nothing, thus the "negation of the nothing" presents itself

${ }^{45}$ GS II, 26.

${ }^{46}$ At a certain point in the text (GS II, 26), the thinker substitutes the term "Etwas ["something"]" for the much more archaic and unused expression "Ichts", which in modern German, both in Rosenzweig's time and ours, figures almost exclusively as a component of the negative term "Nichts [contraction of Nicht-Ichts, that is "not-something", "nothing"]". 
as an event [Ereignis $]^{47}$, a term which the thinker used and which has extremely dense meaning, as well as a rich future in the philosophical debate of the second half of the $20^{\text {th }}$ century. The same negation of the nothing is taken as an act or action $[\text { Tat }]^{48}$. Acting means decidedly breaking with a series of rejected and not experienced possibilities, it means de-ciding, which according to the word's Latin etymology means to cut off, or according to the etymology of the German verb sich ent-scheiden, to separate or divide. Here too we must ask ourselves what this determinate and determinating act means with respect to God.

\subsection{Ontological profile of the "elemental" God}

The way of the "affirmation of the not-nothing" opens before our eyes an essence with a peculiar profile, a thought-of essence, which goes against a certain tradition of thought undefined and undetermined. Instead, the way of the "negation of the nothing" presents to us, an event, or an act, which are understood as decision and choice, and exclude all other possibilities. These two ways will always be treaded anew by the thinker, evidently with different contents, in his later search for the "elemental" figures of the world and of man, in Star I.2 and in Star I.3. If they are applied to the "elemental" God, what configuration will they give us of him?

\subsubsection{Divine nature}

The affirmation of the "not-nothing", applied to the research of positive knowledge about the elemental God, is metaphorically revisited by the thinker and described as the tranquil flow of a spring that spreads out into an ocean that is in-finite, un-limited, all-embracing and un-circumscribable. It is a perennially peaceful ocean, it is absolutely still, its depths unfathomable and inexhaustible. The metaphor seeks to evoke the infinite essence of God, his peculiar nature, his physis. Such an essence is placed under the sign marked "yes", affirmation, position or positivity. This same essence articulates the positive dynamic polarity that profoundly constitutes and distinguishes the figure of the "elemental God".

According to the thinker logic-algebraic symbology is best suited to express the primordial world's configuration - God's nature is marked, in its naked simplicity, by the letter A. The letter A is not preceded by other letters, it is the first one in the series.

Rosenzweig's choice of establishing a second way of access to the figure of the "elemental" God, as if first way were insufficient by itself, opens a relevant speculative problem, which must be faced and resolved. This same choice unveils and enlightens on one hand the deep theoretic intention present in

47 GS II, 26.

48 Ibid. 
Rosenzweig's theorization of the "elemental" God, and on the other hand, its extraordinary and surprising originality.

Exploring the way of the "affirmation of the nothing" in reference to the "elemental" God and this way's arrival point at the essence or infinite nature of God immediately generate an underlying question. What could there ever be within the figure of the elemental God, beyond his infinite essence and nature? Perhaps God does not exhaust himself entirely in his own infinite essence?

The predisposition of a second way of access to the figure of the "elemental" God gives room to the doubt that this God may not exhaust himself at all in his essence, infinite as it is. Within this same God's figure there must then be something other than or different from his essence.

\subsubsection{Divine liberty}

The "negation of nothing", applied to the research of positive knowledge about the "elemental" God, is also metaphorically revisited by the thinker; this time it is seen as the impetuous breaking forth of a jet of water from the dark pond of the divine nothing, or as a hurricane that, from the outside, falls upon the infinite and still ocean of the divine essence. Yet in this case the metaphor's intention appears to be much more problematic than the objective of the metaphor that described the Rosenzweigian understanding of the divine nature. What de-finition, intended as position of a finite being, what de-limitation, what de-termination could ever be produced within the infinite ocean of divine life; furthermore, at whose or what's hand? If all the previous question's terms were given a dynamic, kinetic and procedural meaning, what event or what act could ever take place within this same infinite ocean? Rosenzweig's answer to these questions is extremely simple yet equally surprising. The only processes of de-finition/de-limitation/de-termination which are possible within the infinite ocean of the divine life are thinkable only and exclusively as the product of an abysmal and originary liberty, divine liberty, precisely. The only events or acts that can take place within the divine life are events and acts of liberty. Yet liberty, inasmuch as it de-fines, de-limits and de-termines, as an event or act, cannot but be finite. Should finiteness be then attributed to divine liberty? Rosenzweig effectively maintains this apparently paradoxical thesis by making use of a fundamental clarification. Divine liberty is according to the thinker intrinsically finite because of its own structural configuration as liberty which de-fines, de-limits, de-termines and de-cides. Even so, it is also absolutely infinite, with respect to its possibilities. For God, of course, everything is possible. Yet what "everything" could we ever speak of in the problem structure we are exploring, that is the context of the divine infinite? What could ever be an infinite horizon within which a suitable application of God's unfathomable liberty could be possible? 
In the total absence of other possibilities, the horizon in question could not be represented by anything other than the infinite divine essence or nature. God's unfathomable liberty, though structurally finite, finds its favored intentional objective, its fundamental finality in the infinite ocean of the divine nature or physis. Through the use of algebraic-mathematical logic which the thinker had previously used to describe the divine nature, he now wishes to designate divine liberty with the symbol $\mathrm{A}=$. Once again, the letter $\mathrm{A}$ is chosen to express the absolutely originary and unconditioned character of everything that regards divine life. The = sign indicates the intentional tension of divine liberty toward the other, in this case, toward the infinite nature of God. In this case the other is not other than God, or outside of him, but rather another within the same God.

\subsubsection{Divine vitality}

The force field that intimately constitutes Rosenzweig's figure of the "elemental" God can at this point unfold in the totality of its internal components. The different and opposite polarities which dwell in him and move his depths have now revealed their intimate layout. The "elemental" God's profile is complete. The elemental God unfolds himself in the rich complexity of his two components his nature and his liberty. These two components are working in the irreducible tension that exists between the positivity of the divine nature and the negativity of divine liberty. God is dynamic, kinetic, perennially moving. The divine liberty hurls itself against the divine nature, shaking its most remote foundations. The divine nature infinitely resists the divine liberty's impetus, breaking it, slowing it down, harnessing it. Divine liberty, in its struggle with the divine nature, transforms itself in will; the divine nature's resistance to the divine liberty's impetus is called destiny, moira.

The polar dynamics which occur between divine nature and liberty make up, in all of its complexity, what Rosenzweig calls "divine vitality". The "elemental" God appears to be entirely permeated by an infinite flow of life. The living God who appears at this point, in his irreducible tension between nature and liberty, is presented, in the thinker's beloved algebraic-mathematical-logical symbology, with the equation $\mathrm{A}=\mathrm{A}$.

In light of what has been said so far, we can now more exactly grasp the meaning of the title which Rosenzweig attributes to Star I.1: "God and his being or metaphysics". The elemental God does not present himself as metaphysical because he transcends worldly physis - which at this stage in Rosenzweig's discourse has not even appeared on the horizon. The metaphysical character of the "elemental" God of Rosenzweig - his metà tà phisikà -surprisingly refers to the divine physis. It is as if God were perennially beyond his own essence, his own nature, his own physis. It is as if God incessantly auto-transcended himself, it is as if he were crossed by a deep inner fracture that divides him into 
self-transcendent God and self-transcended God. The deep motor of this kind of divine auto transcendence, occurring within God himself in the absence of anything outside of him, is represented by the same unfathomable freedom of God. Freedom is what gives movement and life to the "elemental" God ${ }^{49}$.

\section{Epilogue}

The elemental-theological meditation developed by Rosenzweig in Star I.1 is much broader and complex than what we have been able to articulate here. Some fundamental elements of Rosenzweig's discourse developed in the Book have been completely omitted. For example one may think, not as an exhaustive list but only as an indicative one, about the philosophical and linguistic falls produced by Rosenzweig's theorization of the "elemental" God, about the rather problematic and questionable philosophical interpretation of the great oriental religious traditions (India and China), which the thinker elaborates, and finally about the budding reflections on philosophy of art which the same thinker draws from his reflection on the "elemental" God.

We would like to conclude our exposition of the subject with some considerations regarding the comparison between the figure of God and the divine that Rosenzweig treats in Star I.1 and with some developments that the theological reflection of the thinker will come to know in the rest of the work.

Rosenzweig thematizes the "elemental" God in Star I.1 and presents him expressly as the result of a philosophical re-elaboration of the mythical God, as thought of in the "pagan" religious tradition of Ancient Greece. According to the thinker this figure was able to grasp, in a particularly ingenious way, some fundamental traits which effectively distinguish the face of what Rosenzweig deemed to be the true God. In philosophical key, Rosenzweig's rethinking of the revealed image of God, which emerges from Biblical Scriptures, will take up and enhance these fundamental traits, not without transfiguring them radically. The "elemental" mythical God will be able to present himself as a sort of singular prophetic pre-announcement of the living God of the biblical tradition, who maintains with the same mythical God a relationship both of continuity and of rupture.

Some quick remarks will help to give a very general idea of the process of transfiguration that, according to the thinker, the biblical revelation will work on the base of the mythical understanding of God.

For Rosenzweig, the biblical God is the result of the mythical God's exit from the impenetrable mystery of his hiddenness. This exit is proposed by

${ }^{49}$ A careful reader of the Star will notice the creatively reworked main sources from which the thinker draws his understanding of the "elemental" God. Because of their relevance, Schelling's later thought on the one hand, and Nietzsche's speculative challenge, on the other, stand out among these sources, which are openly mentioned (GS II, 19-21). 
Rosenzweig as follows. The supreme and unfathomable divine liberty of the "elemental" God is in tension yet remains in equilibrium with the resistance of the divine nature, but the moment of revelation breaks this equilibrium and in a certain sense, breaks through the wall of the divine nature in question, spilling it outside the mythical God's horizon. This breaking through immediately produces a revolutionary restructuring of the polar aspect that distinguished the mythical God. The divine liberty, passing through the divine nature, undergoes a positive inversion of its negative polarity and thus transforms itself in essence. In other words, the mythical God's sovereign free will is transformed in creative power with respect to the world. Divine liberty is thus harnessed and channeled, explicating itself in well determined directions of development, that is to say, in the coordinates that uphold the world's order. Divine creativity thus transforms itself into one of the essential attributes of the revealed God's nature ${ }^{50}$.

The «elemental» divine nature, on the other hand, itself remains, so to speak, branded by the huge impact produced on it by the sovereign and abysmal divine liberty. This also produces a revolutionary restructuring of the overall polar framework which originally marked the mythical God. As a result of divine liberty's impact against the elemental divine nature, the latter also, symmetrically, inverts its polarity which thus is transformed from positive to negative. This means that the divine nature of the elemental God transforms itself into the event or act of the revealed God. If we ask ourselves what this concretely means, we meet with one of the most suggestive concepts which the Star offers its readers. The mythical God's nature, transforming itself into the act or event of the revealed God, transforms itself into an act of love on the part of God toward the human soul to which he reveals himself. In lovingly revealing himself, it is as if God offered or gave man his own nature, his own essence - that which is dearest to him. In this way God dangerously exposes himself to man's acceptance or refusal ${ }^{51}$, but he can enter into dialogue being almost on the same level as a being from which he is separated by an unfillable ontological abyss. God hands himself over lovingly - he consigns his very essence - to human liberty; thus begins the drama which is salvation history.

It is not, of course, possible here to adequately expand on these brief thoughts. Yet, it is sufficient for us to have evoked the ulterior (the "revealed") developments of the "elemental" theological meditation - which the thinker had begun to outline in Star I.1.

\section{Further readings}

Del Prete, M., (2012), Über die Wahrheit des gesunden Menschenverstandes: $Z u$ Rosenzweigs theologia naturalis, in: Yehoyada Amir et al., Faith, Truth and

${ }^{50}$ See GS II, 124-173.

51 The theme of revelation is especially treated in GS II, 174-228. 
40 The Star for Beginners

Reason. New Perspektives on Rosenzweig’s „Star of Redemption“, Freiburg 481-492.

Schmied-Kowarzik, W., (2012), Vom Gottesbeweis zum Erweis Gottes, in: Yehoyada Amir et al., Faith, Truth and Reason. New Perspektives on Rosenzweig's „Star of Redemption“, Freiburg 15-36. 